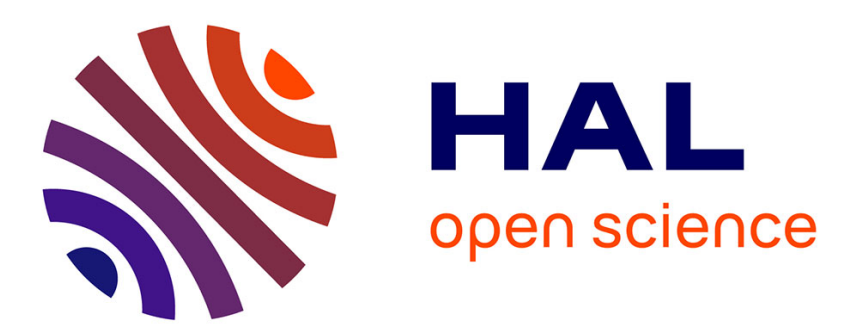

\title{
Everything You Always Wanted to Know About the Summa quadripartita that Descartes Never Wrote
} Sophie Roux

\section{To cite this version:}

Sophie Roux. Everything You Always Wanted to Know About the Summa quadripartita that Descartes Never Wrote. Journal for Early Modern Studies, 2016, 5, pp.171-186. 10.5840/jems2016517 . hal-01493853

\section{HAL Id: hal-01493853 https://hal.science/hal-01493853}

Submitted on 22 Mar 2017

HAL is a multi-disciplinary open access archive for the deposit and dissemination of scientific research documents, whether they are published or not. The documents may come from teaching and research institutions in France or abroad, or from public or private research centers.
L'archive ouverte pluridisciplinaire HAL, est destinée au dépôt et à la diffusion de documents scientifiques de niveau recherche, publiés ou non, émanant des établissements d'enseignement et de recherche français ou étrangers, des laboratoires publics ou privés.

\section{(ㅇ)(1) $\$$}

Distributed under a Creative Commons Attribution - NonCommercial - NoDerivatives $\mid 4.0$ 


\title{
Everything You Always Wanted to Know
}

\section{About the Summa quadripartita that Descartes Never Wrote ${ }^{1}$}

\author{
Sophie Roux \\ École Normale Supérieure, République des savoirs (USR 3608), Mathesis \\ sophie.roux@ens.fr
}

Roger Ariew, Descartes and the First Cartesians, Oxford: Oxford University Press, 2014, $x i x+236$ pp.

Roger Ariew's new book, Descartes and the First Cartesians (hereafter DFC), will not be a methodological surprise for those who already read his previous work, Descartes and the Last Scholastics, ${ }^{2}$ as well as its expanded version, Descartes Among the Scholastics ${ }^{3}$ (hereafter I will refer only to the latter, as $D A S$ ). Right at the beginning of $D A S$, Ariew justified the title of this book in the following way: "A philosophical system cannot be studied adequately apart from the intellectual context in which it is situated. Philosophers do not usually utter propositions in a vacuum, but accept, modify or reject doctrines whose meaning and significance are given in a particular culture. Thus Cartesian philosophy should be regarded $[\ldots]$ as a reaction against, as well as an indebtedness to, the scholastic philosophy that still dominated the intellectual climate" (DAS, p. 1). Moreover, it is not sufficient for the historian to compare Descartes' doctrines with the Aristotelian doctrines; rather, she should "grasp the reasons behind the various opinions" and "beyond that $[\ldots]$ understand the intellectual milieu in which these reasons played a role" (ibid.) In $D F C$, Ariew expresses again the same methodological commitment: "we should not approach Descartes as a solitary, virtually autistic thinker, but as a philosopher who constructs a dialogue with his contemporaries, so as to engage them and various elements of his society in his philosophical enterprise" ( $D F C, \mathrm{p}$. ix).

To approach Descartes' contemporaries not only in so far as they could have been intellectual sources of his thought, but as his peers and colleagues with whom it was not only

\footnotetext{
${ }^{1}$ I wish to thank Sorana Corneanu for her careful editing, Zeta Books and MIT Press for allowing me to reprint a paper originally published in the Journal of Early Modern Studies.

${ }^{2}$ Roger Ariew, Descartes and the Last Scholastics, Ithaca, NY: Cornell University Press, 1999.

${ }^{3}$ Roger Ariew, Descartes Among the Scholastics, Leiden: Brill, 2011.
} 
possible, but also inevitable, that he engaged intellectual discussions has wide consequences. Minores - those "mostly unknown, bizarre-sounding scholastics and Cartesians" (DFC, p. vi) - are to be studied for their own sake. The historian has to read the heavy repetitive volumes that they wrote, or rather, reading these books, she learns to see differences where she previously saw only boring repetitions of one and the same doctrine. Let us recall that Ariew was one of the first scholars to insist on the differences between Scotism and Thomism during the early modern period, and $D F C$ presents new arguments to support the thesis that, at the beginning of the seventeenth century, French, or at least Parisian, scholastics were more Scotist than we had been used to think since Étienne Gilson first published his Index scolastico-cartésien in 1913 (DAS, p. 45; DFC, pp. 4-13, 15-17).

But $D F C$ not only revisits interesting stuff, it also presents new material and does so in a new way. To put it bluntly, it seems to me that there are at least two novelties in $D F C$. First, it takes into account not only scholastics, but as the very title of the book indicates, the "First Cartesians": Ariew's heroes here are Jacques Du Roure, Antoine Le Grand, and PierreSylvain Régis. At this point, however, one might object that there were other Cartesians around the second half of the seventeenth century, even without taking into account luminaries such as Spinoza, Huygens or Leibniz, who were too singular to be merely categorized as Cartesians. Bearing in mind that "Cartesian" was in this period an actor's category, Géraud de Cordemoy, Jacques Rohault, Nicolas Poisson, Louis de la Forge, JeanBaptiste Denis or Bernard Lamy were obviously identified as Cartesians both by Cartesians themselves and by their scholastic enemies. Ariew does discuss them occasionally. Still, although they were among the first Cartesians from a chronological point of view, they are not at the center of Ariew's story in the same way as the triumvirate of Jacques Du Roure, Antoine Le Grand, and Pierre-Sylvain Régis is.

And this is because of the second novelty of $D F C$, which amounts to highlighting the idea that philosophy should be presented in textbooks, that is, as summae quadripartitae. Because of this idea, Ariew applies the category "First Cartesians" not so much to the Cartesians who were the first to follow Descartes' doctrine from a chronological point of view, as to those who were the first to carry out Descartes' unfinished project of writing a textbook in Latin. ${ }^{4}$ As is well known, by the end of 1640, Descartes formulated the project of presenting his philosophy in such a way that it could be taught. Before renouncing this

\footnotetext{
${ }^{4}$ On the two meanings of 'first' in the title Descartes and The First Cartesians, see Martine Pécharman's paper in this issue.
} 
project, Descartes had the time to formulate it in slightly different ways. ${ }^{5}$ But he always insisted that, in order to be taught, his philosophy should be shortened and presented "in order (par ordre)" - as if he was now judging that his previous writings had no order, or at least, recognizing that his order was not everyone's order. ${ }^{6}$ And, even if he considered once the possibility of calling his textbook summa philosophiae, there is no evidence that he ever wanted to extend it further than metaphysics and physics: on the contrary, he presents it as a Latinized version of Le monde. ${ }^{7}$ But, Ariew argues, the book that resulted from this projectPrincipia philosophiae — was inadequate for teaching philosophy: because it did not include logic and ethics, it was incomplete when compared to regular scholastic textbooks. Hence, the task of the "First Cartesians" would have been to write the Cartesian textbook that Descartes had not written and to write it in a form acceptable to their scholastic contemporaries, that is, to write a summa quadripartita (DFC, pp. ix-xi and passim). Desmond Clarke once captured the tendency of Cartesians to behave as sectarians who follow an intellectual Master rather than the truth by speaking of "Scholastic Cartesianism." ${ }^{, 8}$ According to Ariew, Cartesians are not scholastic because of their obedience to Descartes; on the contrary they introduced some variations and innovations with respect to Descartes' doctrine (DFC, pp. 206-209 and passim). But they are scholastics because they wrote books that belong to the genre of summa quadripartita.

Summa quadripartita as a genre indeed shapes the construction of DFC. DAS was a collection of papers that were all written with similar methodological commitments, but that were thematically independent one from the other. On the contrary, $D F C$ is quite systematically constructed as a succession of different summae quadripartitae. A first

\footnotetext{
${ }^{5}$ See Descartes' letters to Mersenne, 11 November 1640, AT III, p. 233; To Mersenne, [December 1640], AT III p. 259; To Mersenne, 31 December 1640, AT III, p. 276; To Huygens, 21 January 1642, AT III, p. 782 . (AT = Oeuvres De Descartes, 11 vols., ed. by Charles Adam and Paul Tannery, Paris: Librairie Philosophique J. Vrin, 1983.)

6 "[...] écrire par ordre tout un Cours de ma Philosophie" (AT III, p. 233); “[...] faire un Abregé, où je mettray tout le cours par ordre” (AT III, p. 259); “[...] écrire ma Philosophie en tel ordre qu'elle puisse estre aisément enseignée" (AT III, p. 276).

7 "Mon Monde se fera bientost voir au monde, \& je croy que ce seroit des à present, sinon que je veux auparavant luy faire aprendre à parler latin; \& je je le feray nommer summa Philosophiae, affin qu'il s'introduyse plus aysement en la conversation des gens de l'escole" (AT III, p. 782).

${ }^{8}$ Desmond M. Clarke, Occult Powers and Hypotheses. Cartesian Natural Philosophy under Louis XIV, Oxford: Oxford University Press, 1989, pp. 222-244. This criticism of the Cartesians was a topos by the end of the seventeenth century. See the notes that Baillet's Vie de Monsieur Descartes inspired to Huygens and his letters to Meier, 26 March 1691 and June 1691, in Euvres complètes de Christian Huygens, ed. by Société Hollandaise des Sciences, 22 vols., La Haye: Martinus Nijhoff, 1888-1950, X, pp. 54, 104, 404-405. See also Leibniz to Huygens, 20 February 1691, in id., p. 52; to Pelisson, 18 March 1692, in Leibniz, Sämtliche Schriften und Briefe, Preussische, ed. by Preussischen (Deutsche) Akademie der Wissenschaften zu Berlin, Darmstadt/Leipzig/Berlin: Akademie-Verlag, 1923-, I-7, p. 292; Leibniz to Claude Nicaise, Journal des scavants, 13 April 1693, pp. 163164.
} 
introductory chapter contrasts Thomism and Scotism, asks the question of what was taught by the different Orders in France, and presents Descartes' changing attitudes to the Jesuits, the Oratorians and the Doctrinaires. Each of the three following chapters is devoted to the different types of text that included similarly titled doctrines: the early seventeenth-century French Aristotelian textbooks in the second chapter, Descartes' own tree of philosophy in the third chapter, and, finally, Cartesian systems in the fourth chapter. ${ }^{9}$ Since each of these three chapters is divided according to the four canonical parts of summae quadripartitae-logic, metaphysics, physics and ethics, albeit obviously following a different order, depending on whether one is a scholastic or a Cartesian $(D F C$, p. xiv, p. xix, n. 19)-, DFC can be read following either the succession of types of text or the succession of philosophical domains.

Regardless of the manner in which one chooses to read it, it is quite precious to be able to count on a tool that helps us draw systematic comparisons between Descartes, the scholastics and the Cartesians. One of the many stimulating aspects of $D F C$ has nothing to do with systematicity, though: this is the fact that, at almost every page, we get a glimpse at small figures previously unmentioned - so that, instead of contemplating from afar only a few unapproachable peaks that would tower above a flat desert, we stroll about in a region full of higher and lower hills, deeper and larger valleys. To say it in less poetical terms, $D F C$ includes a lot of information about the circulation of Descartes' texts and about the construction of Descartes' doctrine as a canonical doctrine, but also about less known philosophers, about the doctrines that they held, about the editions of the books that they published. One of the interesting points that Ariew makes concerning logic is that, by the end of the century, Cartesians and Scholastics converged to write quadripartite logics based on conception, judgment, consequence and method ( $D F C$, p. 165). Being not myself a metaphysician by nature, I learned a lot about univocity and equivocity ( $D F C$, pp. 51, 57 , 100-102, 117-120, 177-179) and about the different early modern theories of distinctions (DFC, pp. 101-102, 113-122, 165-166, 177-178). Many fascinating points would be worth pursuing. Before coming to broader issues, I would like to pick up and discuss two minor claims, the one concerning physics, the other concerning ethics.

In the section devoted to Descartes' physics, Ariew rightly argues that this physics has little to do with the discourses about the mathematization of the world-picture that were fashionable in Edwin Arthur Burtt's and Alexandre Koyré's times (DFC, pp. 131-137, 187-

\footnotetext{
9 "Descartes' tree" is a strange expression here: Ariew argues that it was not Descartes' exclusive property; contrary to Descartes' own presentation (AT IX-2, p. 14), for the sake of symmetry with the preceding chapter and with the following, he includes logic in this tree, but excludes from it medicine and mechanics ( $D F C$, pp. 106-107).
} 
190). ${ }^{10}$ However, I would like to qualify one of the three claims defended in the section "Hypotheses and Moral Certainty" of the third chapter. Here are these claims: "(1) Descartes frequently used the concept [of moral certainty] before his formal definition of it in the Principles [...]. (2) Descartes borrowed the concept from the Schoolmen [...]. And (3) against most commentators, despite what could be inferred from Descartes' examples of code-breaking and of knowing where Rome is, moral certainty should not be equated with high probability" (DFC, pp. 143-144). I completely agree with the two first claims, but I would like to qualify the third one. If I understood it well, Ariew's main argument in favor of this claim is not conceptual, but historical. Conceptually, one could believe that the examples brought out by Descartes in Principia philosophiae IV 205-believing that a code was broken and that there is a city called Roma in Italy - admit of degrees of certainty and that the probability that such beliefs are true is higher if a longer code was broken or if we can rely on a greater number of testimonies that Roma is an Italian city. But, says Ariew, moral certainty does not admit of degrees: it would have been, for Descartes as for the Scholastics, an absolute entity, since certainty and probability were separated as demonstrative science and probable opinion. It is true that the distinction between certainty and probability was such a strong distinction that Descartes and the Cartesians never felt free to admit that they were advancing only probable hypotheses. ${ }^{11}$ However, as has been established by Sven K. Knebel in the context of post-Tridentine theology, Jesuits from the early seventeenth century proposed a distinction between three types of possible, which was quickly applied to other notions, such as causality, freedom, indifference, evidence and certainty. ${ }^{12}$ The thirteenth century had established a distinction between, on the one hand, the possibile physice, physical power, and, on the other, the possibile metaphysice, logice or mathematice, defined by the conceivability or at least the non-contradiction of the terms of the proposition at stake. A second distinction was added in the early seventeenth century, the distinction between possibile physice and possibile morale, where the former is the power which a being has in

\footnotetext{
${ }^{10}$ It would be difficult for me not to agree: Ariew refers to the introduction I wrote for a special issue of Early Science and Medicine (Forms of Mathematization (14th-17th Centuries), Volume 15, Issue 4-5, 2010), in which I argued that, even if we did not believe anymore in the big picture of the Scientific Revolution there were still many work do be done about what "mathematization" implied for different authors in the Medieval, Renaissance and Early Modern Period.

${ }^{11}$ This was a leading fad in the first book written in English about the natural philosophy of the French Cartesians, Desmond Clarke's Occult Powers and Hypotheses. See in particular pp. 183-200, 229-232, 243244.

${ }^{12}$ Sven K. Knebel, Wille, Würfel und Wahrscheinlichkeit Wille, Würfel und Wahrscheinlichkeit. Das System der moralischen Notwendigkeit in der Jesuitenscholastik 1500-1700, Hambourg: F. Meiner, 2000. See also id., "The Renaissance of Statistical Modalities in Early Modern Scholasticism," in R. L. Friedman and L. O. Nielsen (eds.), The Medieval Heritage in Early Modern Metaphysics and Modal Theory, 1400-1700, Dordrecht: Kluwer, 2003, pp. 231-251.
} 
general to do or not to do something, while the latter is that power in so far as it can be associated with extrinsic circumstances that favor its actualization or, on the contrary, hinder it, in other words, that power in so far as it is sometimes actualized. Where this becomes interesting for us is that idea that, in so far as the moral possibility is sometimes actualized but sometimes not, it is capable of some quantification; the Jesuit texts use an eloquent analogy with a dice game in order to illustrate the difference between what is physically possible (all the possible outcomes) and what is morally possible (the outcome that finally obtains when the dice is rolled). As such, this distinction would demonstrate the reestablishment of a statistical conception of modalities, which would constitute the conceptual womb in which the theory of probabilities developed. ${ }^{13}$ To say it in a word, Knebel established that the distinction between moral certainty and physical certainty was formed in a context where the analogy with dice games implied a certain measure of quantification. In this sense, Ariew's claim that, historically, moral certainty admits of no degree and is not to be equated with high probability should be qualified.

Ariew shows quite convincingly the role that Claude Clerselier's edition of Descartes' letters played in the elaboration of a Cartesian ethics (DFC, pp. 153-156). But I would like to discuss the claim that "the Cartesians created a Neo-Stoic ethics" $(D F C$, pp. 206-207, 209). Descartes himself entertained subtle relations to Stoic ethics, which indeed underwent a striking revival in the seventeenth century (DFC, pp. 150-151). ${ }^{14}$ It was noted long ago that the second maxim of the Discourse on Method has a Stoic allure and that Descartes recommended Élisabeth to read Seneca's De vita beata. ${ }^{15}$ But we also know that, at the same time, Descartes criticizes the Stoics because "they do not adequately explain how to recognize a virtue, and often what they call by this fine name is nothing but a case of callousness, or vanity, or desesperation, or parricide." debatable, it is Le Grand that I would like to discuss more closely here. Before his conversion to Cartesianism, Le Grand wrote two ethics books in French, Le Sage des Stoïques and

\footnotetext{
${ }^{13}$ Sven K. Knebel, Wille, Würfel und Wahrscheinlichkeit, pp. 148-156. If I may refer to my own work, $L$ 'Essai de logique de Mariotte. Archéologie des idées d'un savant ordinaire, Paris: Classiques Garnier, 2011, pp. 95-98, analyses how Mariotte adapted the distinction between three kinds of possibles to physics.

${ }^{14}$ See also Jacqueline Lagrée, Juste Lipse et la restauration du stö̈cisme: Étude et traduction des traités stö̈ciens De la constance, Manuel de philosophie stö̈cienne, Physique des stoïciens, Paris: Vrin, 1994; Id., Le néostö̈cisme. Une philosophie par gros temps, Paris: Vrin, 2010.

${ }^{15}$ Descartes to Élisabeth, 21 July, 4 August, 18 August 1645, AT IV, pp. 253, 263-268, 277; Discours de la méthode, AT VI, p. 129. See the references and comments given by Étienne Gilson in his edition of Discours de la méthode, Paris: Vrin, 1925.

${ }^{16}$ Discours de la méthode, AT VI, p. 129.
} 
L'Épicure spirituel. ${ }^{17}$ The first and most popular of these books defended the theses that wise men can live without passions, that passions are not natural to human beings, and that they do not help them to develop their virtues. After his conversion to Cartesianism, however, Le Grand changed his mind on passions and he explicitly distanced himself from his former book:

I confess my self formerly to have pleaded their Cause [that is, the cause of the Stoics] in my Discourse entitled, L'Homme sans Passions, and not only to have maintained SENECA's Opinion, but also according to my slender Ability, endeavour'd to advance and exalt it. But forasmuch as I now follow the sentiments of DES CARTES, and my business is not to explain the Opinions of others, but only to lay open Truth, no understanding man will reproach me of Lightness or Inconstancy, for going about to unfold the usefulness of the Passions, and leaving the Stoicks, consider Man, not as translated amongst the Glorified Saints in Heaven, but as placed amongst his Mortal Brethren here on Earth."18

My point is obvious: if Le Grand thought that his former Stoic beliefs and his more recent Cartesian beliefs on passions were not compatible, can we really call his doctrine "neoStoic"?

I may have qualifications to make and questions to ask, but they are obviously dependent on the many things that Ariew taught me to see and understand. Now, in the following, I would like to put $D F C$, or at least its last chapter on Cartesians, in a somewhat broader perspective. It cannot be denied that there were some Cartesians who wrote books organized as summae quadripartitae and that some of these books were intended for teaching. One should be grateful to Ariew for having explored in such detail these books, as well as other books written by Cartesians. However, it seems to me that Ariew's scholastic perspective leads him to entangle teaching Cartesianism and writing summae, writing summae and writing systems. In the following discussion, I would like to disentangle these different elements and ask the two following questions: First, while Descartes insisted that some order should be introduced in his philosophy if it was to be taught in the schools, what has such an order to do with the presentation of philosophy as a system or as a summa quadripartita? Second, what did teaching philosophy mean for Descartes and his followers?

\footnotetext{
${ }^{17}$ Le Sage des Stö̈ques, ou l'homme sans passions, selon les sentiments de Sénèque, The Hague: Samuel Broune and Jean L'Escluse, 1662; L'Épicure spirituel, ou, L'empire de la volupté sur les vertus, Paris: Pierre de La Forge, 1669. There were many reprints of these books, some of them with slightly different titles.

${ }^{18}$ Antoine Le Grand, The Institution, in An Entire Body of Philosophy, trans. R. Blome, London: Roycroft, 1694, Part X, chap. 13, §1, pp. 367-368.
} 
It is precisely in the second half of the seventeenth century, while Ariew's Cartesians were busy writing their summae, that our notion of a system was elaborated. The term "system" is attested in French since 1552; however, until the mid-seventeenth century, it referred, as its Latin equivalent "systema," to the cosmological order of the planets, or, more rarely, in music, to a sequence of intervals. ${ }^{19}$ However, during the second half of the seventeenth century, its use spread and it began to designate any kind of order and disposition. As Bouhours noted en 1675:

Il y a quelques années, que ce mot n'estoit connu en notre langue que des philosophes et des mathématiciens; c'était un mot d'art en quelque sorte, le système du monde, le système de Copernic. Depuis que M. de la Chambre a fait le système de l'âme, on s'est accoutumé à ce mot, \& comme il signifie proprement constitution \& situation, on s'en est servi dans le figuré, pour exprimer bien des choses. $^{20}$

Furetière, after mentioning the use of "sistème" in astronomy, notes that it is also used in physics and in medicine:

On appelle aussi en Physique le sisteme des sens, du mouvement, de la nourriture, \&c., la manière dont on suppose \& on conçoit que ces organes sont disposes. Entre les Medecins il y en a qui suivent le sisteme des saveurs; l'autre qui suivent le sisteme des quatre qualités, d'autre le sisteme des acides et des alcalis. Ce Medecin fait un nouveau sisteme des fièvres. ${ }^{21}$

Régis himself, in the dictionary that he inserted at the end of the first volume of his Physique, has an entry "physics," where he gives a general definition of a system: "ce qui fait qu'une chose agit d'une certaine manière en vertu de sa composition et des dispositions qui font sa nature," then he mentions not only the systems of the world, but also, like Furetière, the systems of the senses, of motion, of food. Interestingly enough, though, Régis ends up his

\footnotetext{
${ }^{19}$ Ulrich Ricken, "Quelques aspects de l'évolution du champ notionnel Ordre-Système au XVII ${ }^{\mathrm{e}}$ siècle," in M. Fattori and M. Bianchi (eds.), Ordo. Atti del II. Colloquio Internazionale del Lessico Intelletuale Europeo (Roma, 7-9 gennaio 1977), Roma: Edizioni dell'Ateneo e Bizzarri, 1979, pp. 471-487.

${ }^{20}$ Dominique Bouhours, Remarques nouvelles sur la Langue française, Paris: Sébastien Mabre-Cramoisy, 1675, p. 57-58. Cureau de la Chambre, Système de l'Ame, Paris: Jacques d'Allin, 1664, Préface, justified indeed the title of this book in the following way: "Je n'ai pû trouver de terme qui expliquast bien mon dessein, que le mot de Systeme. Car de luy donner pour titre Discours de la Nature de l'Ame, il est esté trop vague. [...] De luy donner aussi celuy des Actions de l'Ame, il eust esté trop resseré. [...] De sorte que apres avoir remarqué que les Astronomes en faisant le Systeme du Monde, qui n'est autre chose que l'ordre \& la disposition qu'ils donnent à tous les corps dont le Monde est composé, n'examinent point la nature de ces corps-là, et ne cherchent que leur situation, leur figure, leur grandeur \& leurs mouvemens, j'ai creû que je pouvois emprunter d'eux ce terme-là, puisque j'avois les mêmes visées pour le regard de l'Ame."

${ }^{21}$ Furetière, Dictionnaire universel, Paris: A. and R. Leers, 1690, article "sistème."
} 
entry with a comparison between a hypothesis and a system, which implies that the word "system" does not only refer to the structure and composition of things, but, also, to propositions that are ordered in such a way that they compose a coherent whole:

“L'Hypothèse est un Système plus particulier, et le Système une Hypothèse plus générale, ou, pour mieux dire, le Système n'est qu'un composé de plusieurs Hypothèses." 22 It is however in the Avertissement that opens his Physique that Régis gives the most precise definition of this new meaning of "système": "Nous entendons par SYSTÈME non une seule hypothèse, mais un amas de plusieurs hypothèses, dépendantes les unes des autres et tellement liées avec les premières vérités qu'elles en soient comme des suites et des dépendances nécessaires."23 Here, Régis could have taken inspiration from Descartes: there are several passages where Descartes, as a duelist who would challenge his enemy, exclaimed that if this or that proposition is false, then, the whole of his philosophy is false. Though Descartes may have borrowed the image of a tree from Abra de Raconis and transferred it from physics to the whole of philosophy, I am not sure that Abra de Raconis ever stressed the coherence of his propositions in this way.

To sum up, the word "système," which was used mainly with reference to the disposition of the planets, began to designate the disposition of anything, including, in the case of a Cartesian like Régis, the order and disposition of propositions in a book. Ariew is not concerned with such new meanings. And that's because he does not believe that his heroes formulated systems in the sense of consistent sets of propositions depending on a few basic tenets. With a fully British sense of understatement, Ariew notes that "in his 1654 Philosophy, Du Roure tries to follow an order sketched by Descartes, though he does not integrate all the materials completely" (DFC, p. 161), that "despite his enthusiasm [...] Du Roure's Morale, like his Logique, gives the impression of something that has not fully come together" (DFC, p. 195), or, still, that Régis' Système général "is a very odd work $[\ldots]$ [which] does not seem very systematic" (DFC, p. xii). I could not find any similar quotations concerning Le Grand, but he surely does not fare better. Still, the fact that Du Roure, Régis and Le Grand failed to be systematic does not imply that they had not the intention of being systematic, to wit, of proposing a coherent set of hypotheses depending on a few basic tenets. In the case of Régis at least, this was quite important, since he thought - it is immaterial here to know if he was justified to think so - that the difference between the

\footnotetext{
${ }^{22}$ Régis, article “système,” Dictionnaire inséré à la fin de la Physique, in Système de Philosophie, Paris: Anisson, Posuel, Rigaud, 1690, vol. I, n.p.

${ }^{23}$ Avertissement, La Physique, in id., vol. I, pp. 275-276.
} 
arbitrary hypotheses advanced by Claude Perrault in his Essays de physique and his own true hypotheses in physics was precisely that his hypotheses were organized in a system. The Avertissement I already quoted goes on in the following way:

\begin{abstract}
Ce qui [i.e., that all the hypotheses are like necessary consequences of first truths] ne sçauroit convenir aux hypotheses purement arbitraires, telles que sont celles de la plus-part des Philosophes modernes. Il n'y a rien de plus commun que les hypotheses arbitraires [...]. Il n'en est pas de meme des systèmes que des hypotheses arbitraires [...]. Nous nous servirons donc comme les autres, du droit de faire des hypotheses [...]. Mais pour n'en établir que d'exactes, nous ferons ensorte qu'elles dependent absolument des premières verités. ${ }^{24}$
\end{abstract}

Thus, Régis' Système général can be seen as a summa quadripartita, but it can also be read as a system of hypotheses that are presented as true because they depend on first truths and form a coherent whole. Consequently, it seems to me that we could conjecture that the first Cartesians contributed to forge our notion of a system, not so much because they wrote summae quadripartitae, as because they tried both to establish the supremacy of their works over works like Perrault's Essays and to answer the criticisms about framing hypotheses that was addressed to them. In any case, it is interesting to note that what Descartes described as presenting his philosophy "in order" gave way to at least two interpretations that were different but not incompatible: on the one hand, it meant complying with the order of domains and disciplines that was canonical in summae quadripartitatae; on the other hand, it meant insisting on the coherence of all the propositions together.

In the second place, I would like to insist that studying scholastic textbooks and Cartesian systems should not make us forget that Descartes and his followers raised wideranging questions about the teaching of philosophy—namely, where, how, by whom and to whom was philosophy to be taught?

First, let us come back to Descartes himself. As I have already noted, Ariew's project finds its origins in the letters where, by the end of 1640, Descartes formulated the project of presenting his philosophy in such a way that it could be taught in the Schools, which implied to shorten it, to order it differently, and to put it in Latin. These are important letters for understanding the genesis of Descartes' Principia philosophiae. However, these are not the only things that Descartes wrote about how his philosophy could be taught; he seems to have been especially careful to delineate the kind of students whom he was addressing himself to.

\footnotetext{
${ }^{24} \mathrm{Ibid}$. The relation between hypothesis and system is discussed in Clarke, Occult Powers and Hypotheses, pp. $215-221$.
} 
On the one hand, he asserted that his writings might be studied virtually by everybody. Thus, in a letter to Vatier, Descartes explained that in Discours de la méthode, he did not dare to explain in detail why our beliefs concerning material beings can be subject to doubt, because "these thoughts did not seem to me suitable for inclusion in a book which I wished to be intelligible in part even to women." 25 On the other hand, he insisted that his readers should not be excessively learned. For example, at the very beginning of La recherche de la vérité, he explained that an honnête homme "is not required to have read absolutely every book or diligently mastered everything that is taught in the Schools. It would, indeed, be a kind of defect in his education if he had spent too much time in book-learning (en l'exercice des lettres). ${ }^{26}$ In other words, Descartes was at the same time encouraging those who may have hesitated to approach his writings because they were uneducated and insisting that, in the case of those who were well educated, all their learning was not enough. The condition sine qua non was in both cases to be ready to spend time, care and attention enough in perusing Descartes' books. In the Lettre-Préface to Principes de la philosophie, he rehearsed the idea:

I should like to assure those who are over-diffident about their powers that there is nothing in my writings which they are not capable of completely understanding provided that they the trouble to examine them. I would, however, also like to warn the others that even the most excellent minds will need a great deal of time and attention in order to look at all the things which I set myself to include. ${ }^{27}$

My point is not to play Descartes the honnête homme against Descartes the scholastic. Being not a Martin Schoock rediviva, neither is it not to claim that Descartes wanted us to stop reading books. (According to Schook's Admiranda Methodus, Descartes required from his disciples to forget all the books and the whole tradition of learning in order to submit themselves to Descartes as to their master. ${ }^{28}$ But, in fact, if Descartes condemned those who spend too much time studying books, he did not, for that, condemn reading books in general.) But I think that Descartes' description of his ideal readers may have contributed to making it possible that philosophy reached other readers than the captive audience of boisterous students, and that French Cartesians realized this possibility.

\footnotetext{
${ }^{25}$ Descartes to Vatier, 22 February 1638, AT I, p. 560, transl. CSM III, p. 86. (CSM = The Philosophical Writings Of Descartes, 3 vols., trans. by John Cottingham, Robert Stoothoff, and Dugald Murdoch (Volume 3 including Anthony Kenny), Cambridge: Cambridge University Press, 1988.)

${ }^{26}$ La recherche de la vérité, AT X, p. 495, transl. CSM II, p. 400, to be compared with the criticism of those who spent all their time in schools (Regulae ad directonem ingenii, AT X, p. 371).

${ }^{27}$ Lettre-Préface, Principes de la philosophie, AT IX-B, p. 13.

${ }^{28}$ Théo Verbeek (ed.), La Querelle d'Utrecht, Paris: Les impressions nouvelles, 1988, pp. 189, 197 and passim.
} 
Among Cartesians, there were not only professors, but also authors and monitors, as Malebranche would have put it, worldly experimentalists like Jacques Rohault, and, further, polished conversationalists like Bernard Le Bovier de Fontenelle. ${ }^{29}$ Many testimonies indicate that, from the sixties on, the teaching of Cartesian philosophy in France was not confined to the regular teaching institutions such as the collèges de plein exercice and the universities. Rather, Cartesian philosophy was taught in conférences or private academies and discussed in salons. The description that the Cartesian Clerselier gives of the audience of Rohault's Mercredis - "people of all stations and conditions, prelates, abbots, courtesans, doctors, physicians, philosophers, geometers, regents, schoolboys, provincials, foreigners, artisans, in a word, people of all ages, sex and profession" 30 — concords with one of the many reproaches that the Doctrinaire Jean Vincent made to Toulouse's Cartesians, among which the most famous one was Pierre-Sylvain Régis: "they divulge to all kind of human beings, kids, adults, men, women, the doctrine that in the Schools used to be diffused to only a few men." 31 The only difference between Clerselier and Vincent is that the former gives credit to this kind of mixed and motley audience, while the latter would have liked to discredit it completely.

Thus, in late seventeenth-century France, honnêtes gens, among whom some women, who were learned but not specialized, able to read short philosophy books but not ready to spend time on heavy summae, good Christians but not furious theologians, were the ones to be convinced. ${ }^{32}$ It seems to me that, by focusing on the genre of summae quadripartitae and, thus, implicitly, on the official teaching of philosophy that took place in collèges de plein exercice and universities, Ariew sometimes misses what he himself called in DAS the "intellectual milieu" in which controversies continuously emerged between Cartesians, Scholastics and even other species of philosophers in France by the end of the seventeenth century, an "intellectual milieu" which, some fifty years afterwards, was already different from the intellectual milieu in which Descartes himself worked. To put it more precisely, if

\footnotetext{
${ }^{29}$ For a study of the various social figures of the philosopher, see Dinah Ribard, "Philosophe ou écrivain? Problèmes de délimitation entre histoire littéraire et histoire de la philosophie en France, 1650-1850," Annales HSS, 2 (2000), pp. 355-388.

${ }^{30}$ Claude Clerselier, Préface, Euvres posthumes de Rohault, ed. by Claude Clerselier, Paris: Guillaume Desprez, 1682, n.p. Other sources attest to the fact that a certain number of persons of quality, young students (for example Pierre-Sylvain Régis) and women (for example Madame de Bonneveaux or Madame de Guerderville) attended these lectures.

${ }^{31}$ Jean Vincent, Discussio peripatetica in qua philosophiae cartesianae principia ... dilicude examinantur, Toulouse: Colome and Posuel, 1677, IV, sect. 526, p. 521. Bernard Le Bovier de Fontenelle, Éloge de M. Régis, in Euvres complètes. Tome VI. Paris: Fayard, 1994, pp. 143-144, explains that Régis' success was such that the magistrates of the city awarded him a pension.

${ }^{32}$ This is one of the things that I tried to show in Sophie Roux, "A French Partition of the Empire of Natural Philosophy (1670-1690)”, in Daniel Garber and Sophie Roux (eds.), The Mechanisation of Natural Philosophy, New York, Dordrecht, Boston, London: Kluwer, 2012, pp. 55-98.
} 
Ariew's point is to describe the variety of Cartesian doctrines at the end of the seventeenth century, especially in as much as they paradoxically appeared in the scholastic form of a summa, I cannot but repeat that I admire without any reserve the fine-grained description that he succeeded in giving of such a doctrinal variety in such a short volume. But, when Ariew implies that the success of Cartesianism in France at this period is to be explained by the Cartesian textbooks that Du Roure, Régis and Le Grand wrote, I cannot agree. ${ }^{33}$ If this is the explanandum, one should go beyond the genre of the summa and admit that other social forces were at stake.

This is all the more true since the books taken by Ariew as typical for this genre, the books by Du Roure, Le Grand and Régis, although all organized as summae, did not have the same audience from a quantitative point of view, did not play the same role in the reception of Descartes' philosophy in France, and did not contribute in the same way to shape French Cartesianism. I launched a systematic search in Catalogue collectif de France: I retrieved less than 20 copies of Le Grand's Institutio philosophiae secundum Renati Descartes nova methoda adornata et explicata, ${ }^{34} 20$ copies also of all the books written by Du Roure, about 60 copies of Régis' Système général, 75 copies of Fontenelle’s Entretiens sur la pluralité des mondes and, finally, 120 copies of Rohault's Traité de physique. Du Roure seems to have printed his books in his own house, which was no more a good sign at that time than it would be now, and I have almost never seen him mentioned in the exchanges of the late seventeenth century. The only known Cartesian to have exchanged with Du Roure may have been Johann Clauberg. Du Roure met Clauberg in Paris in 1648. In a compilation of Cartesian papers published in Amsterdam in 1683 under the title Cartesiaanse redden-konst: met het onderscheid tusschen de Cartesiaanse en schoolse philoosophie, Dutch translations of Clauberg, Dilly and Du Roure are to be found. ${ }^{35}$ It is moreover to be noted that at the end of his Initiatio philosophi, Clauberg quotes a letter that Du Roure sent him after reading the Defensio; in this letter, Du Roure suggested to dub those who follow Descartes "rational philosophers (Philosophes Raisonnables)" because the foundation of Descartes' philosophy

\footnotetext{
${ }^{33}$ DFC, p. 205: "Thus the Cartesians were able to replace the Aristotelians in the Schools. How exactly did they accomplish that? Well, they tried to supplant the Aristotelians by producing Cartesian textbooks that would teach the whole collegiate curriculum [...] in a Cartesian mode. They attempted a revolution across all aspects of the curriculum, not just in the sciences and metaphysics."

${ }^{34}$ The Historia naturae, variis experimentis et ratiociniis elucidata, secundum principia stabilita in Institutione philosophiae, which, before being published as the third part of An Entire Body of Philosophy, was much more popular than the Institutio.

${ }^{35}$ DFC, p. 191, n. 138.
} 
would have been to accept "only what we conceive and what Reason can teach us." ${ }^{36}$ Le Grand was more important than Du Roure. Perhaps because his Institutio philosophiae had been the object of a quite brief notice in Journal des scavants on 20 February 1679, he was known by Pierre Bayle, Antoine Arnauld and the Jesuit Louis Le Valois. ${ }^{37}$ But what these authors write when they mention him seems to indicate that they had not really read him, except perhaps for Bayle, and that it was simply difficult to know exactly who he was. His audience was not French, but English: he lived in England from the age of 27 to his death; except for the three books that he published in French before his conversion to Cartesianism, he published in Latin or English; he dedicated the different editions of his Institutio to the Academici Cantabrigiensis universitatis; finally it is to be noted that he engaged controversies only with English philosophers, to wit Samuel Parker and John Sergeant. As for Régis, he was indeed quite important, even if not as important as Rohault. But although he had a long career of public teacher and personal preceptor, contrary to Le Grand who wrote the Institutio "in usum juventutis Academicae," he does not seem to have published his Système général for students, and in any case he was never studied in collèges or universities.

In a word, studying Du Roure, Le Grand and Régis is interesting in itself and challenging as such. But, beyond that, understanding their "intellectual milieu" would imply to differentiate the French context of the forties, in which Descartes himself made his works known, from the French context of the fifties and early sixties, in which Du Roure published some of his books in his own house; further, to distinguish those two contexts from the French context of the eighties and nineties, in which Régis published a Cartesian textbook while the Académie des sciences was flourishing; and, finally, to set apart those three contexts from the English context, where, thanks to Recusant families, a Catholic missionary like Le Grand could survive in an overtly anti-Catholic England.

Ariew concludes his introduction with the following words: "Much work remains to be done; as Descartes would have said: I leave this task to my 'nephews - and to my nieces

\footnotetext{
${ }^{36}$ Johann Clauberg, Initiatio philosophiae cartesianae sive Dubitatio cartesiana, ad metaphysicam certitudinem viam aperiens, Leiden: A. Wyngaerden, 1655, pp. 436-437. I thank Domenico Collacciani for this reference.

${ }^{37}$ Pierre Bayle to Jacob Bayle, April or May 1679, at http://bayle-correspondance.univ-st-etienne.fr/?Lettre-168Pierre-Bayle-a-Jacob; in the article "Rorarius," Dictionnaire historique et critique, Rotterdam, 1715, p. 442, Le Grand's Dissertatio de carentia sensus \& cognitionis in brutis is mentioned among other Cartesians publications concerning animal machines; Système abrégé de philosophie, in Euvres diverses de M. Pierre Bayle, La Haye: La Compagnie des Libraires, 1737, IV, p. 426, alludes to Le Grand's physics. Antoine Arnauld, Lettres au Père Malebranche, in Euvres completes de Messire Antoine Arnauld, Paris: S. d'Arnay, 1775-1783, XXXIX, p. 150: "Vous pouvez voir ce qu'en dit dans sa philosophie cartésienne le Père Antoine le Grand, que j'apprends etre un religieux de Saint François". Louis Le Valois, Sentimens de M. Descartes touchant l'essence et les proprietez des corps corps, opposez à la doctrine de l'Eglise, et conforme aux erreurs de Calvin, sur le sujet de l'Eucharistie, Paris: Étienne Michallet, 1680, I, chap. 4, p. 84.
} 
too, of course.' I just hope to have provided an initial path into these complex materials" (DFC, p. xix). He may be wrong as regards these last words: he did much more than "providing an initial path," he opened many new paths for us all. But he is definitively right when he underlines that much work remains to be done to understand the complex reception of Descartes in France and elsewhere.

\section{Works Cited}

Roger Ariew, Descartes and the Last Scholastics, Ithaca, NY: Cornell University Press, 1999.

Roger Ariew, Descartes Among the Scholastics, Leiden: Brill, 2011.

Antoine Arnauld, Lettres au Père Malebranche, in Euvres completes de Messire Antoine Arnauld, vol. XXXIX, Paris: S. d'Arnay, 1775-1783.

Pierre Bayle, "Lettre 168: Pierre Bayle à Jacob Bayle," in Correspondance de Pierre Bayle, vol. III, online edition at http://bayle-correspondance.univ-st-etienne.fr/?Lettre-168-Pierre-Bayle-a-Jacob.

Pierre Bayle, Dictionnaire historique et critique, Rotterdam (Geneva: Fabri et Barrillot), 1715.

Pierre Bayle, Système abrégé de philosophie, in Euvres diverses de M. Pierre Bayle, vol. IV, La Haye: La Compagnie des Libraires, 1737.

Dominique Bouhours, Remarques nouvelles sur la Langue française, Paris: Sébastien Mabre-Cramoisy, 1675.

Desmond M. Clarke, Occult Powers and Hypotheses. Cartesian Natural Philosophy under Louis XIV, Oxford: Oxford University Press, 1989.

Johann Clauberg, Initiatio philosophiae cartesianae sive Dubitatio cartesiana, ad metaphysicam certitudinem viam aperiens, Leiden: A. Wyngaerden, 1655.

Claude Clerselier, "Préface," CEuvres posthumes de Rohault, ed. by Claude Clerselier, Paris: Guillaume Desprez, 1682.

Cureau de la Chambre, Système de l'Ame, Paris: Jacques d'Allin, 1664.

René Descartes, Discours de la méthode, ed. by Étienne Gilson, Paris: Vrin, 1925.

René Descartes, Oeuvres De Descartes, 11 vols., ed. by Charles Adam and Paul Tannery, Paris: Librairie Philosophique J. Vrin, 1983.

René Descartes, The Philosophical Writings Of Descartes, 3 vols., trans. by John Cottingham, Robert Stoothoff, and Dugald Murdoch (Volume 3 including Anthony Kenny), Cambridge: Cambridge University Press, 1988.

Bernard Le Bovier de Fontenelle, Éloge de M. Régis, in Euvres completes, vol. VI, Paris: Fayard, 1994.

Antoine Furetière, Dictionnaire universel, Paris: A. and R. Leers, 1690.

Christian Huygens, Euvres complètes de Christian Huygens, ed. by Société Hollandaise des Sciences, 22 vols., La Haye: Martinus Nijhoff, 1888-1950.

Sven K. Knebel, Wille, Würfel und Wahrscheinlichkeit Wille, Würfel und Wahrscheinlichkeit. Das System der moralischen Notwendigkeit in der Jesuitenscholastik 1500-1700, Hamburg: F. Meiner, 2000. 
Sven K. Knebel, “The Renaissance of Statistical Modalities in Early Modern Scholasticism,” in R. L. Friedman and L. O. Nielsen (eds.), The Medieval Heritage in Early Modern Metaphysics and Modal Theory, 1400-1700, Dordrecht: Kluwer, 2003, pp. 231-251.

Jacqueline Lagrée, Juste Lipse et la restauration du stö̈cisme: Étude et traduction des traités stoïciens De la constance, Manuel de philosophie stö̈cienne, Physique des stö̈ciens, Paris: Vrin, 1994.

Jacqueline Lagrée, Le néostoïcisme. Une philosophie par gros temps, Paris: Vrin, 2010.

Antoine Le Grand, Sage des Stö̈ques, ou l’homme sans passions, selon les sentiments de Sénèque, The Hague: Samuel Broune and Jean L'Escluse, 1662.

Antoine Le Grand, L'Épicure spirituel, ou, L'empire de la volupté sur les vertus, Paris: Pierre de La Forge, 1669.

Antoine Le Grand, An Entire Body of Philosophy According to the Principles of the Famous Renate des Cartes, trans. Richard Blome, London: Roycroft, 1694.

Louis Le Valois, Sentimens de M. Descartes touchant l'essence et les proprietez des corps corps, opposez à la doctrine de l'Eglise, et conforme aux erreurs de Calvin, sur le sujet de l'Eucharistie, Paris: Étienne Michallet, 1680.

Gottfried Wilhelm Leibniz, Sämtliche Schriften und Briefe, Preussische, ed. by Preussischen (later: Deutsche) Akademie der Wissenschaften zu Berlin, Darmstadt/Leipzig/Berlin: Akademie-Verlag, 1923-.

Pierre-Sylvain Régis, Système de Philosophie, Paris: Anisson, Posuel, Rigaud, 1690.

Dinah Ribard, "Philosophe ou écrivain? Problèmes de délimitation entre histoire littéraire et histoire de la philosophie en France, 1650-1850," Annales HSS, 2 (2000), pp. 355-388.

Ulrich Ricken, "Quelques aspects de l'évolution du champ notionnel Ordre-Système au XVII siècle," in M. Fattori and M. Bianchi (eds.), Ordo. Atti del II. Colloquio Internazionale del Lessico Intelletuale Europeo (Roma, 7-9 gennaio 1977), Roma: Edizioni dell'Ateneo e Bizzarri, 1979, pp. 471-487.

Sophie Roux, "Forms of Mathematization $\left(14^{\text {th }}-17^{\text {th }}\right.$ Centuries)," Early Science and Medicine, 15, 2010, p. 319337.

Sophie Roux, L'Essai de logique de Mariotte. Archéologie des idées d'un savant ordinaire, Paris: Classiques Garnier, 2011.

Sophie Roux, “A French Partition of the Empire of Natural Philosophy (1670-1690)," in Daniel Garber and Sophie Roux (eds.), The Mechanisation of Natural Philosophy, New York, Dordrecht, Boston, London: Kluwer, 2012, pp. 55-98.

Théo Verbeek (ed.), La Querelle d'Utrecht, Paris: Les impressions nouvelles, 1988.

Jean Vincent, Discussio peripatetica in qua philosophiae cartesianae principia [...] dilicude examinantur, Toulouse: Colome and Posuel, 1677. 